\title{
KARAKTERISTIK MORFOLOGI ULAR FAMILIA ELAPIDAE DI KAMPUS UNIVERSITAS ANDALAS LIMAU MANIH PADANG
}

\author{
Fachrul Reza $^{1}$, Djong Hon Tjong ${ }^{2}$, Wilson Novarino ${ }^{2}$ \\ ${ }^{1}$ Program Studi Pendidikan Biologi STKIP PGRI Sumatera Barat \\ ${ }^{2}$ Jurusan Biologi FMIPA UNAND \\ e-mail: gm_theviper@yahoo.co.id
}

\begin{abstract}
Research on the Snakes Morphological Characteristics on Campus of Andalas University Limau Manih had been done. The research was conducted using survey method and Dissemination of Information to Public accompanied by morphometric measurements and descriptions. The results of the research that had been done caught 2 species that consist of one family namely Elapidae. This family is refer to snakes which has neurotoxin venom glands, no loreal scalation, and mostly teresterial. Maticora bivirgata flaviceps (Cantor, 1839) which has no loreal scale, red coloration on tail, and head; Naja sumatrana Müller, 1887 which has no loreal scale, black coloration with yellow coloration on it's hood, and yelowish head.
\end{abstract}

Key words: Elapidae, Biodiversity , Campus of Andalas University

\section{PENDAHULUAN}

Ular adalah reptil yang mudah dikenali, diklasifikasikan kedalam ordo Squamata, subordo Serpentes (Ophidia). Terdapat 25002700 jenis ular dalam 414 genus dan 13 famili di dunia terdistribusi di seluruh permukaan bumi kecuali daerah Artik, Islandia, Selandia Baru, dan beberapa pulau kecil di lautan luas (Obst et al., 1988). Memiliki ukuran panjang antara 150-11400 mm, tetapi kebanyakan 250$1500 \mathrm{~mm}$. Hampir semua ular teresterial, banyak juga yang hidup di liang, di air tawar atau air asin, bahkan memanjat pohon. Bentuk ular umumnya memanjang tidak berkaki, tidak memiliki lubang telinga, tetapi mempunyai perasa yang sangat sensitif dan memiliki reseptor kimia. Pada beberapa jenis ular terdapat organ penangkap pancaran panas. Warna tubuh umumnya coklat, abu-abu, atau hitam namun ada juga merah terang, kuning, atau hijau dengan bercak/bintik/gelang/garis yang bervariasi (Halliday dan Adler, 1986).
Supriatna (1981) melaporkan bahwa di Indonesia terdapat sekitar 400 jenis dengan sekitar 110 jenis yang berbisa atau sekitar 30\%. Ular berbisa tersebut kebanyakan hidup di laut dan hanya sekitar 35 jenis saja yang hidup di darat. Jika diekstrapolasikan dengan angka, maka hanya $8 \%$ ular berbisa yang hidup di darat dari seluruh jenis ular di Indonesia. Jenis ular yang terdapat di Indonesia telah diteliti oleh beberapa peneliti antara lain mengenai ular kobra yang sangat berbeda dibandingkan Malaysia, Tailand, Jawa bahkan pulau-pulau kecil disekitarnya (Wuster dan Thorpe, 1987), tentang biogeografi ular di Indonesia (How dan Kitchener, 1997), tentang genus Trimeresurus yang berwarna hijau dan coklat berasal dari Indonesia bagian barat telah dilakukan oleh ahli taksonomi asing selama sepuluh tahun terakhir (Malhotra \& Thorpe, 2000, 2004; David et al., 2001, 2002; Vogel et al., 2004; David dan Vogel, 2006 cit Sanders et al (2005)). David dan Vogel,1996 menuliskan bahwa di pulau Sumatera terdapat sekitar 128 jenis. 
Pulau Sumatera merupakan pulau terbesar ketiga di Indonesia terletak di garis khatulistiwa, beriklim tropis dan memiliki Pegunungan Barisan dari utara ke selatan. Masih banyaknya daerah Sumatera yang ditutupi hutan dan vegetasi lainnya menyebabkan keanekaaragam jenis ular yang tinggi. Terdapat 128 jenis, yang telah dilaporkan di Sumatera terdiri dari dari famili Typhlopidae sebanyak empat jenis yang merupakan hewan endemik Sumatera $(3,1 \%$ dari jumlah ular keseluruhan di Sumatera); Anomochilidae sebanyak satu jenis $(0,8 \%)$; Cylindrophiidae sebanyak satu jenis $(0,8 \%)$; Xenopeltidae sebanyak satu jenis $(0,8 \%)$; Pythoninae sebanyak dua jenis $(1,6 \%)$; Acrocordidae sebanyak dua jenis $(1,6 \%)$; Colubridae sebanyak 99 jenis, 22 diantaranya merupakan hewan endemik Sumatera $(77,9 \%)$; Elapidae sebanyak delapan jenis $(6,3 \%)$ dan Viperidae sebanyak sembilan jenis $(7,19 \%)$ (David dan Vogel,1996). Namun demikian informasi mengenai biologi, ekologi, penyebaran dan taksonomi ular di Sumatera masih sedikit demikian juga di Sumatera Barat.

Kampus Universitas Andalas Limau Manih termasuk HPPB yang terletak di Sumatera Barat memiliki keanekaragaman hayati yang sangat tinggi, (Azmardi, 1998) melaporkan kurang lebih 89 jenis burung, Sulasta, (2008) menemukan 18 jenis katak, dan Hendri (2008) melaporkan 10 jenis tikus. Hewan-hewan tersebut sangat erat kaitannya dengan ular, karena merupakan mangsa bagi ular. Namun sejauh ini belum ada informasi mengenai keanekaragaman jenis ular di Kampus UNAND Limau Manih termasuk HPPB. Informasi tersebut tentunya diperlukan dalam upaya pelestariannya dan penanganan kasus gigitan ular. Pada kasus gigitan ular informasi tentang jenis ular (jenis) dan jenis racun sangat dibutuhkan untuk menentukan langkah awal pertolongan di lapangan.

\section{METODE PENELITIAN}

\section{Survei dengan transek}

Penentuan lokasi transek dilakukan dengan pertimbangan habitat yang disukai oleh ular seperti semak, tepian sungai, akar pohon, percabangan pohon, liang bebatuan dan serasah pada lantai hutan. Kemudian survei dilakukan sepanjang transek sepanjang satu kilometer disertai penangkapan langsung objek yang ditemukan. Transek dilakukan di empat lokasi berbeda yaitu UPT (Unit Pelaksanaan Teknis) Peternakan dan Kandang Penelitian Fakultas Peternakan, UPT Pertanian dan Kebun Tanaman Obat Farmasi, HPPB (Hutan Pendidikan dan Penelitian Biologi) dan areal kampus (gedung kuliah, kantor fakultas, rektorat dan lain-lain) selain itu, jika dijumpai di sekitar areal penelitian tetap ditangkap. Bila terjadi kasus gigitan ular akan ditangani dengan cara terlampir.

\section{Pengumpulan Informasi}

Informasi dari masyarakat dikumpulkan dengan menyebarkan Pamflet pengumuman yang ditempel di lokasi keramaian (kafe, gedung kuliah dan kantor) di kampus UNAND Limau Manih. Pengambilan sampel dilakukan ke lokasi setelah didapat informasi dari masyarakat.

Preservasi

Spesimen diinjeksi dengan formalin $4 \%$ pada bagian atas kepala, kemudian diinjeksi dengan formalin $4 \%$ pada beberapa bagian tubuh yang berongga dan ditutupi dengan tisu yang telah dibasahi formalin, kemudian dibiarkan selama satu malam. Setelah semalam spesimen dipindahkan kedalam botol sampel berisi alkohol $70 \%$.

\section{Identifikasi Sampel}

Identifikasi sampel dilakukan di Laboratorium menggunakan buku-buku kunci identifikasi yaitu: Cox et al., 1998, David dan Vogel, 1996, Malkmus et al., 2002 dan Vogel, 2000

Pengukuran Morfometrik dan Deskripsi

Pengukuran morfometrik dilakukan pada setiap spesimen yang ada Museum Zoologi Universitas Andalas dan spesimen dari lapangan. Karakter yang diukur dan diamati adalah pengukuran karakter mensural yaitu Panjang Kepala, Panjang Ekor, Diameter Mata, Panjang Moncong dan Panjang Total, serta penghitungan karakter numerik yaitu Jumlah sisik intra-occular (JSIO), Jumlah sisik supra- 
occular (JSSO), Ada-tidaknya sisik pre-occular (SP), Jumlah sisik supra-labial (JSSL), Jumlah sisik infra-labial (JSIL), Ada-tidaknya sisik temporal (ST), Ada-tidaknya sisik loreal (SL), Jumlah Sisik Lingkar Badan (JSLB), Jumlah Sisik Ventral dan Jumlah Sisik Ekor. Dilakukan deskripsi setiap jenis yang didapat.

\section{HASIL DAN PEMBAHASAN}

\section{Jenis yang Didapat}

Dari penelitian yang dilakukan di kampus UNAND Limau Manih pada bulan April 2009 sampai Maret 2010 didapatkan dua puluh jenis ular yang tergolong ke dalam 18 genus dan 5 famili. Jenis ular berbisa yang didapatkan selama penelitian adalah Maticora bivirgata flaviceps, Naja Sumatrana (Elapidae) dan Tropidolaemus wagleri (Viperidae), Boiga cynodon (Colubridae) sedangkan ular yang tidak berbisa adalah Ahaetulla prasina prasina, Chrysopelea paradisi paradisi, Dendrelaphis caudolineatus caudolineatus, Dendrelaphis formosus, Dendrelaphis pictus, Gonyosoma oxycephalum, Liopeltis tricolor, Lycodon subscinctus Subscinctus, Oligodon octolineatus, Opisthotrophis rugosus, Pseudorabdion eiselti, Rabdophis chrysargos, Xenelaphis hexagonotus dan Xenochrophis trianguligerus.

Penelitian Iskandar dan Setyanto (1996) di Lembah Anai hanya mendapatkan 14 jenis dari 5 famili, sedangkan Iskandar dan Prasetyo (1996) di Pulau Pini hanya mendapatkan 8 jenis dari 4 famili dengan famili Laticaudidae tidak didapatkan pada lokasi kampus UNAND yang terletak di pulau utama yaitu Pulau Sumatera.

Tersedianya makanan dan habitat yang cocok memungkinkan ular untuk hidup dan menetap disuatu tempat. Pada penelitian ini didapat data yang sedikit berbeda dari buku panduan, yaitu didapatkannya Gonyosoma oxycephalum dan Maticora bivirgata flaviceps. Kedua jenis tersebut merupakan ular yang mendiami daerah kebun dan hutan, jarang ditemukan di pemukiman, gedung atau keramaian seperti areal kampus. Hal ini terjadi disebabkan oleh ketersediaaan makanan berupa binatang-binatang pengerat, suhu yang cocok, vegetasi atau sarang yang cocok dan kelembaban yang mendukung. Maticora bivirgata flaviceps merupakan ular teresterial yang memangsa ular lain kadal ataupun katak didapatkan di jalan kampus dan di teras belakang stasiun HPPB, kedua lokasi didapatkannya ular ini sangat mendukung keberadaannya, di lokasi ini terdapat liang-liang pada selokan berair tergenang yang dangkal, katak dan kadal yang cukup banyak serta suhu yang mendukung.

\section{Deskripsi \\ Family Elapidae}

Sisik lingkar badan kurang dari 50, mempunyai taring , kepala tidak begitu lebar/membulat, leher tidak jelas, badan sedikit ramping, tidak mempunyai loreal pit, sisik loreal dan pupil bulat.

3.2.2.1. Maticora bivirgata flaviceps (Cantor, 1839)

Maticora bivirgata flaviceps (Cantor, 1839), Blue Long Glanded Coral Snake ( Cox et al., 1998) (p.29), Nama Lokal: Tampuang Ari.

Kepala membulat berwarna merah, rostral tumpul, memiliki sisik temporal, tidak memiliki loreal pit, tidak memiliki sisik loreal, sisik bagian atas kepala besar, mata hitam dengan pupil bulat besar berwarna hitam pekat. Badan bulat panjang dengan sisik berlunas berwarna hitam, bagian lateral memiliki garis biru dikedua sisi dan bagian ventral berwarna merah dengan sisik lempeng. Tidak terdapat Sendok pada bagian leher. Ekor berwarna merah pada bagian dorsal, bagian ventral dengan sisik berpasangan.

Kisaran ukuran dan jumlah sisik yang didapat di lapangan dari dua spesimen (K 030, K 031) : PK 11,9-12,5 mm ; PE 53,75-77 mm ; PT 495-700 mm ; Tidak Memiliki LP; Tidak Memiliki SL; Memiliki SP; DM 1,4-1,65 mm ; PM 4,2-4,4 mm ; JSIO 6 ; JSSO 3 ; JSSL 6-7 ; JSIL 6-9 ; JSLB 13-15 ; Memiliki ST; JSV 228274 ; JSE 38-47 pasang. 


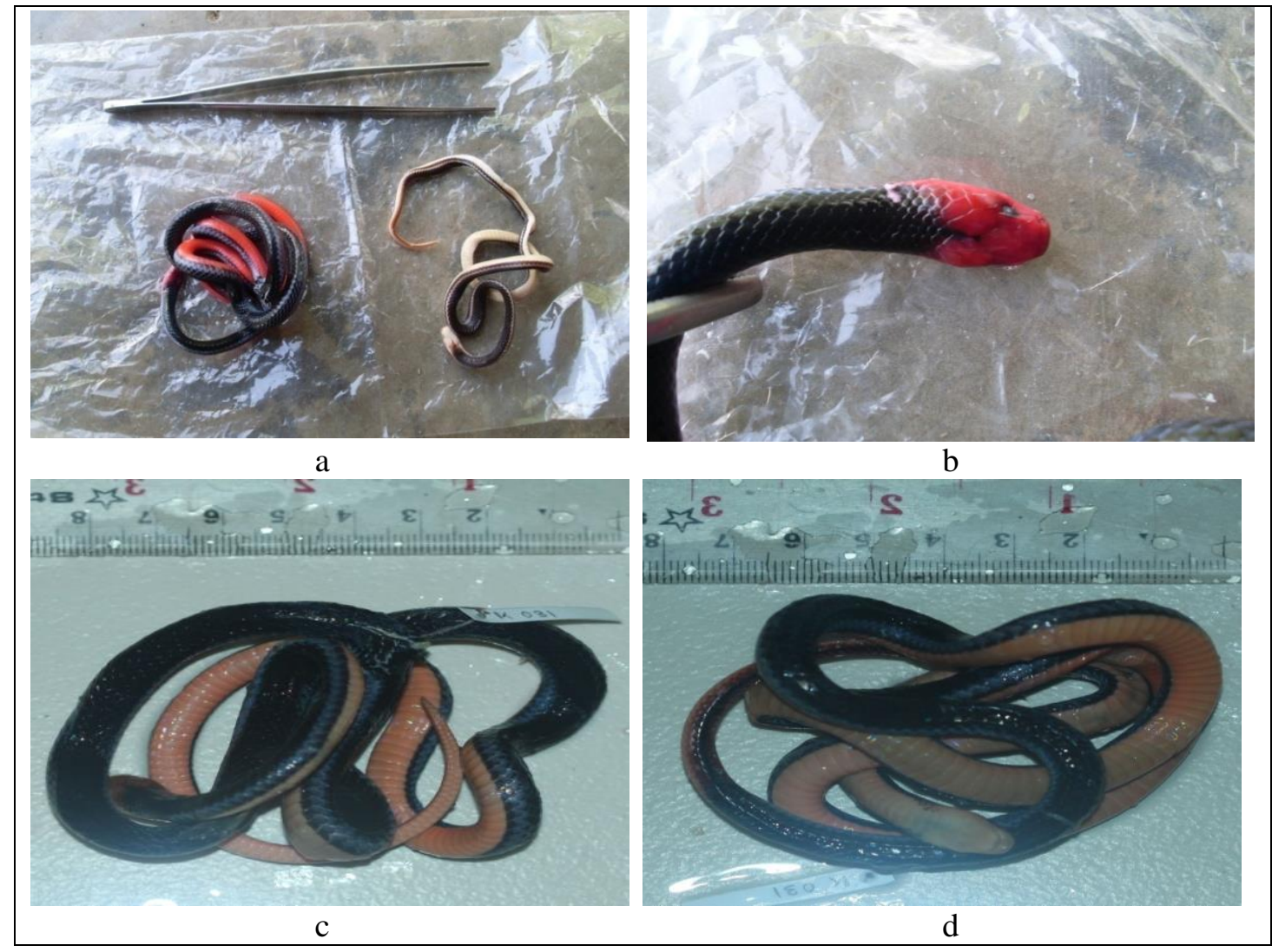

Gambar 22. Maticora bivirgata flaviceps (Cantor, 1839) a. Sebelum dan Sesudah Diawetkan, b. Kepala, c. Dorsal, d. Ventral.

Sesuai dengan yang dideskripsikan oleh Cox et al., (1998): ekor dan kepala berwarna merah, badan berwarna biru gelap berkilau, terdapat garis biru sepanjang tepi badan dan bagian ventral berwarna merah. Ular ini memiliki panjang $1400 \mathrm{~mm}$.

Ular ini jarang ditemukan, nokturnal ditemukan di daerah hutan dataran rendah sampai ketinggian $500 \mathrm{mdpl}$. Jenis ini memangsa ular lain, mungkin juga kadal dan katak. Bertelur 1-3 butir. Tersebar di Thailand sebelah selatan, Malaysia Barat, Singapura, Miyanmar dan sebagian daerah Indonesia.(Cox et al., 1998).

\section{Naja sumatrana Muller, 1887}

Naja sumatrana Muller, 1887 (Malkmus et al., 2002) (Fig.371.,p.308), Equatorial Spitting (Cobra Cox et al., 1998) (p.29), Nama Lokal: Ula Sanduak
Kepala Membulat berwarna kuning (Juvenille) atau hitam (Dewasa), rostral tumpul, memiliki sisik pre-occular, tidak memiliki sisik loreal, tidak memiliki loreal pit, sisik bagian atas kepala besar, memiliki sisik temporal, mata hitam dengan pupil bulat berwarna hitam besar terdapat bercak kuning pada bagian lateral leher bersambung hingga bagian ventral. Badan bulat panjang dengan sisik berlunas berwarna hitam dan bagian ventral berwarna hitam kelabu dengan sisik lempeng. Serta terdapat Sendok (Hood) pada bagian leher. Ekor berwarna hitam pada bagian dorsal dan putih kelabu pada bagian ventral dengan sisik berpasangan.

Kisaran ukuran dan jumlah sisik yang didapat di lapangan dari satu spesimen (K 014) : PK $11 \mathrm{~mm}$; PE84 mm ; PT 595 ; Tidak Memiliki LP; Tidak Memiliki SL; Memiliki SP; DM 2,95 mm ; PM 5,7 mm ; JSIO 7 ; JSSO 4 ; 
Fachrul Reza, F., Tjong, D, H., Novarino, N. 2016. Karakteristik Morfologi Ular Familia Elapidae di Kampus Universitas Andalas Limau Manih Padang. Journal of Sainstek 8(2): 135-141

JSSL 7 ; JSIL 9 ; JSLB 17 ; Memiliki ST; JSV 198 ; JSE 53 pasang.

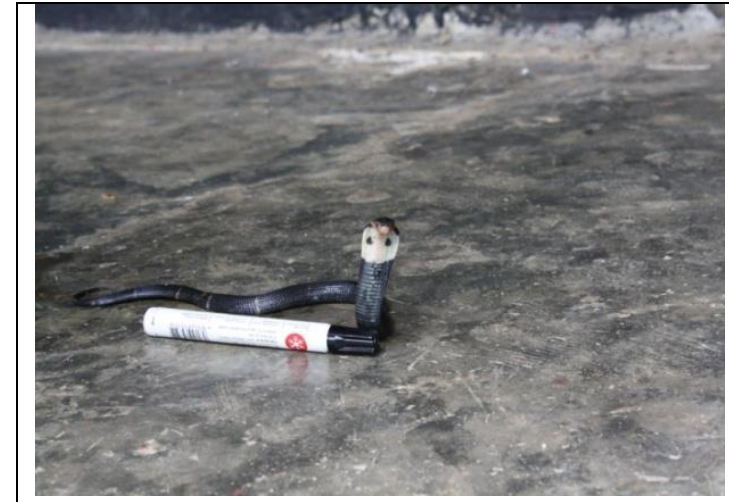

a

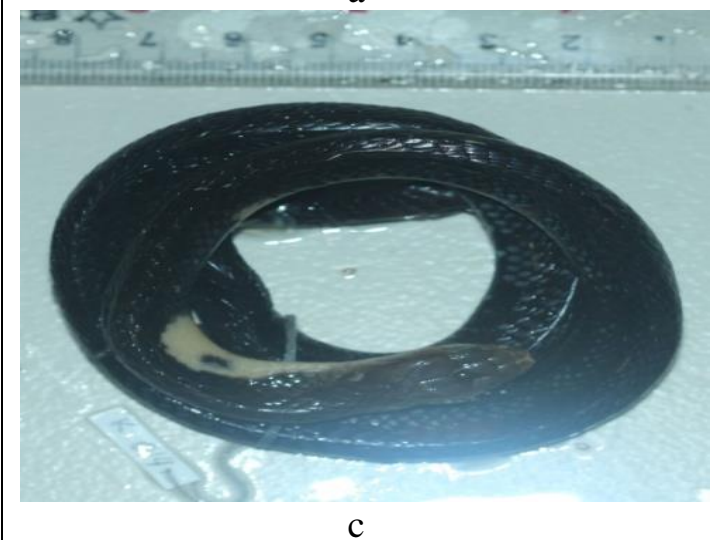

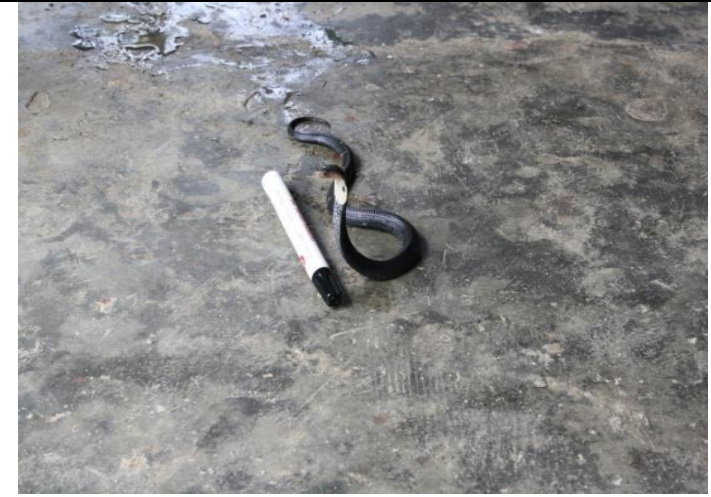

$\mathrm{b}$

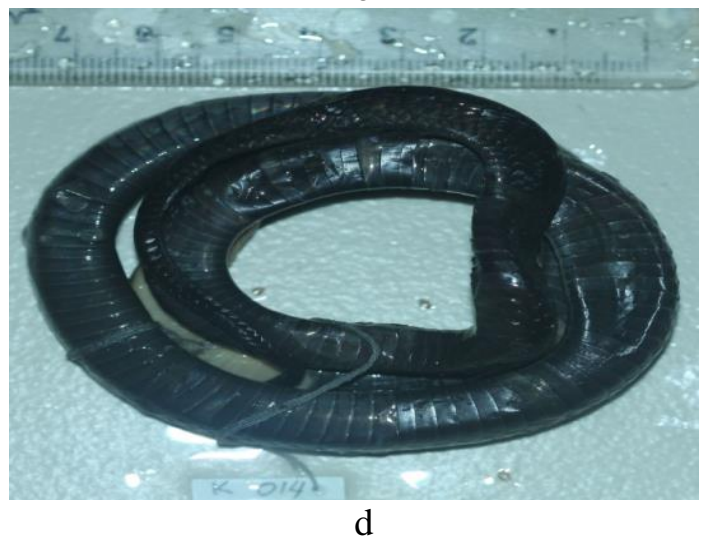

Gambar 23. Naja sumatrana Muller, 1887 a. Hood, b. Lateral, c. Dorsal, d. Ventral.

Sesuai dengan yang dideskripsikan oleh Cox et al., (1998): memiliki fase kuning dan fase hitam. Pada fase kuning, tubuh berwarna kuning atau hijau menguning dengan beberapa sisik bertepi hitam, kepala berwarna kuning gelap dan labial berwarna kuning terang, mata berwarna gelap dan lidah berwarna merah muda. Pada fase hitam semua bagian tubuh berwarna hitam kecuali dagu, kerongkongan dan ventral. Ular ini memiliki panjang 1600 $\mathrm{mm}$.

Naja sumatrana ditemukan di dataran rendah dan daerah berbukit sampai ketinggian 1500 mdpl. Jenis ini mendiami pinggiran hutan basah dataran rendah tropis dan hutan kering dataran rendah tropis khususnya sepanjang daerah hutan yang telah ditebang, hutan pegunungan tropis dan subtropis, rawa-rawa, tanah belukar, perkebunan (di mana ia merasa cocok), kawasan budidaya, padi sawah, kebun dan perkotaan. Jenis ini sering ditemukan di tempat-tempat basah padat di sekitar tumbuhan air. Naja sumatrana adalah ular terresterial meskipun dapat berenang dan aktif malam hari, bersarang pada lubang yang sesuai dengan ukuran tubuhnya dan sering dijumpai di pemukiman manusia. Memangsa mamalia, terutama tikus, dan amfibi, kadal, burung dan juga ular. Tidak agresif meskipun menampilkannya sikap defensif ketika terganggu dan menyerang bila terpojok.Ular ini dapat menyemburkan bisa kepada penggangunya dan merupakan ular berbisa yg mematikan. Tersebar dari Semenanjung Malaya dan Kalimantan hingga P. Palawan di Filipina, 
Fachrul Reza, F., Tjong, D, H., Novarino, N. 2016. Karakteristik Morfologi Ular Familia Elapidae di Kampus Universitas Andalas Limau Manih Padang. Journal of Sainstek 8(2): 135-141

merupakan jenis asli pulau Sumatra dan pulaupulau kecil sekitarnya.(Malkmus et al., 2002).

\section{DAFTAR KEPUSTAKAAN}

Azmardi. 1998. Jenis-jenis Burung di Kawasan Hutan Pendidikan dan Penelitian Biologi (HPPB) Universitas Andalas. Skripsi Sarjana Biologi. FMIPA Universitas Andalas, Padang

Cox JM. 1998. A Photographic Guide to Snakes and Other Reptiles of Peninsular Malaysia, Singapore and Thailand. New Holland Publishers (UK) Ltd. London.

David $\mathrm{P}$ et al. 2006. A Revision of The Trimeresurus Puniceus Complex Based on Morphological and Molecular Data. Zootaxa 1293: 1-78

And G. Vogel. 1996. Snake of Sumatra Seconde Edition. Edition Chimaira. Frankfurt, Germany . 2000. On the Occurences of Trimeresurus Alholabris ( GPA 1842) on Sumatera Island, Indonesia. Senckenbergiana Biologica 80 (1/2): 225-232

Delsman HC. 1974. Seri Alam Terbuka No. 43: Ular. Ganaco N.V. Bandung

Halliday $\mathrm{T}$ and Adler K. 1986. The Encyclopedia of Reptilles and Amphibians. Fact on File. New York

Hendry. 2008. Jenis-jenis Tikus (Muridae) di Hutan Pendidikan dan Penelitian Biologi (HPPB) Universitas Andalas. Skripsi Sarjana Biologi. FMIPA Universitas Andalas, Padang

How RA and DJ Kithchener. 1997. Biography of Indonesian Snakes. Journal of Biogeography 24, 725-735

Iskandar DT and WR Erdelen. 2006. Conservation of Amphibians and Reptiles in Indonesia: Issues and Problems. Bandung: Institut Teknologi Bandung.

Iskandar DT and DY Setyanto. 1996. The Amphibians and Reptiles of Anai Valley, West Sumatra. Annual Report of FBRT Project No 2

Kuch et al. 2007. A New Species of Temple Pit Viper (Tropidolaemus Wagleri, 1830) from Sulawesi, Indonesia (Squamata: Viperidae: Crotalinae). Zootaxa 1446: 120

Malhotra A and RS Thorpe. 2000. A Phylogeny of the Trimeresurus group of Pit Viper: New Evidence from a Mitochondrial Gene Tree. Molecular Phylogenetics and Evolution Vol. 16, No.2, August, pp.199211

.2004

A

Phylogeny of Four Mitochondrial Gene Regions Suggest A Revised Taxonomy for Asian Pit Viper (Trimeresurus and Ovophis). Molecular Phylogenetics and Evolution 32: 83-100

Malkmus et al. 2002. Amphibians \& Reptiles of Mount Kinabalu (North Borneo). A.R.G. Gantner Verlag K.G. Germany.

Obst FJ et al. 1988. Atlas of Reptiles and Amphibians for the Terrarium. T.F.H. Publications.inc. United State of America

Phelps T. 1981. Poisonous Snakes. Blandford Press Ltd. UK

Rahman MA, Salsabila R, Tamin, dan S Eka P. 1991. Inventarisasi Flora dan Fauna. Rencana Induk Pengembangan dan Pengelolaan Universitas Andalas. BAPPEDA TINGKAT I SUMBAR. Padang.

Sanders KL et.al. 2004. Ecological Diversification in a Group of Indomalayan Pitvipers ( Trimeresurus ). Convergence in Taxonomically Important Traits has Implications for Species Identification. Journal of Evolutionary Biology Vol. 17, Issue 4, Pages 721-731

Sanders KL et.al. 2005. Combining Molecular Morphological and Ecological Data to Infer Species Boundaries in a Cryptic Tropical Pitviver. Biological Journal of the Linnean Society, 87, 343-364

Sulasta. 2008. Komunitas Anura (Amphibia) Sungai dan Hutan di HPPB Universitas Andalas. Skripsi Sarjana Biologi. FMIPA Universitas Andalas, Padang

Supriatna J. 1981. Ular Berbisa Indonesia. Bhratara Karya Aksara. Jakarta 
Fachrul Reza, F., Tjong, D, H., Novarino, N. 2016. Karakteristik Morfologi Ular Familia Elapidae di Kampus Universitas Andalas Limau Manih Padang. Journal of Sainstek 8(2): 135-141

Vogel G et al. 2004. A Review of Morphological Variation in Trimereserus Popeiorum with the Description of Two New Species. Zootaxa: 727: 1-63
Wuster W and RS Thorpe. 1987. Geographic Variation in the Cobras of the Genus Naja In Southeast Asia: A Multivariate Analysis. Departement of Zoology. Proceedings of the 4th Ordinary General Meeting of the Societas Europaea Herpetologica. 